\title{
XXXVII. Description of the Kauri or Cowdee resin, from New Zealand; with experiments in relation to its employment in the arts
}

\section{J. Prideaux}

To cite this article: J. Prideaux (1838) XXXVII. Description of the Kauri or Cowdee resin, from New Zealand; with experiments in relation to its employment in the arts, Philosophical Magazine Series 3, 12:74, 249-254, DOI: 10.1080/14786443808649428

To link to this article: http://dx.doi.org/10.1080/14786443808649428

曲 Published online: 01 Jun 2009.

Submit your article to this journal $[\pi$

Џll Article views: 2

Q View related articles $\llbracket$ 
cells. $d$. pollen-tubes. $e$. embryc. $f$. cæcal cavities of the émbryo-sac in the parenchyma of the cvule. g. funiculus.

Fig. 25. Anther-cells of Pinus abies inclosing four pollen-forming cells.

Fig. 26. The same, after absorption of the parent cells : a grain of pollen may be perceived in each.

Fig. 27. The same after they have been immersed in water: two grains of pollen are just about to leave the cells; having burst the parietes.

Fig. 28. A single grain of pollen from the same.

Fig. 29. Two pollen-bearing cells of Podostemon ceratophyllum.

Fig. 30. Pollen of Podostemon ceratophyllum taken from the stigma, from one of which a pollen-tube already proceeds.

XXXVII. Description of the Kauri or Cowdee Resin, from Nerw Zealand; with Experiments in Relation to its Employment in the Arts. By J. Prideaux, M. Plym. Instit., \&c.*

THE Kauri wood was noticed by Captain Cook as a very fine mast timber, and has since taken the attention of other navigators. Missionaries have been particularly struck with it, and attempts have been made to bring home cargoes of it to this country. 'These attempts are at last successful, and some cargoes have arrived for the dockyard here (Plymouth), fully bearing out the high reputation it had previously attained.

Mr. Yate + describes the tree under the name of "Dammara australis, or Pinus Kauri," as running from 85 to 95 feet high without a branch, and sometimes 12 feet diameter, yielding a $\log$ of heart timber 11 feet diameter. One he measured, perfectly sound, 40 feet 11 inches circumference.

The wood has much the appearance of deal, and works well under the plane, yielding a strong odour of the resin.

The appearance of the tree he describes as most majestic, raising its head far above the other trees of the forest, and crowned with the most splendid foliage; its leaves small and numerous, not unlike those of the English box.

From the trunk, he says, oozes a gum insoluble in water, and, he believes, in rectified spirit; also a kind of resin, answering the purpose of resin in ship-building: both having a strong resinous smell; the gum very fragrant, and chewed+ on that account by the natives. Both gum and resin diffuse themselves over the whole tree, the cone and leaf being

* Communicated by the Author.

+ Account of New Zealand, \&c. Seeley and Burnside. London, 2nd edition, 1835. p. 36. [An account of the Dammara Australis, and a notice of its resin, will be found in Lambert's Genus Pinus, vol. ii. p. 65.-EDit.]

f A material brought home by Mr. George Bennett, to whom we are indebted for much information on the Oceanic Islands, and said to be used by the New Zealanders as a masticatory, under the name of Mimika, was put into my hands two or three years since by Lieut.-Col. Hamilton Smith. 
equally tinctured with it, whilst it may be seen exuding from the tips of the leaves on the highest branches.

The term "gum" appears to be here misapplied to a substance insoluble in water, and I suppose, with deference to Mr. Yate, that his distinction is unfounded; that the gum means the more recent exudation, which is white, opake, fragrant, and more or less compressible, from the presence of its essential oil ; the resin that which has lost by time or exposure the essential oil and a little moisture, and thus become hard and transparent. A piece which was given to me twelve months since in the former state, had become yellow, hard, transparent, and almost inodorous before I repeated my examination of it on the present occasion; and in looking over several cwts. now in this port, I find it in every stage of the difference.

In Berzelius's Traité de Chimie (v. 501) is described a Resine Dammara lately introduced, as transparent, colourless or yellowish, insipid, inodorous, sp. gr. 1.097 to 1.123 , very fusible, without any odour, dissolving partially in alcohol, almost entirely in æther, and completely in oil of turpentine and fat oils. Brandes found in it traces of gum and succinic acid, and two resins; one soluble in cold alcohol, amounting to 83.1 per cent., the remainder insoluble in that menstruum cold, but dissolving in it hot and precipitating in the form of a voluminous snow-like white powder. It will appear that this is not the same with kauri resin, although possessing considerable analogy with it.

Kauri resin (known here as Cowdee gum) is in pieces of various magnitude, from that of a nutmeg to a block of two or three cwts. Generally they are of irregular shape, with rough powdery surface, and often pieces of bark or occasionally even earthy matter attached; whilst some are shining, with a vitreous fracture. In colour they vary from milk-white to deep amber and even brown; the white having occasional transparent lines and patches; the yellow being generally transparent; and the brown sub-opake, apparently from impurity, and perhaps extractive matter. But bits may be found transparent and colourless, and every shade affords abundant examples of milky opacity. Its hardness is intermediate between that of copal and of resin, so that it cannot be scratched by the nail; the milky pieces more or less tough and elastic;

It is black, not quite hard, but friable, breaking like pitch, tasteless and inodorous. On subjecting it to chemical examination, I found it chiefly to consist of asphaltum, containing no kauri resin, as it dissolved entirely in cold oil of turpentine. 
fracture bright vitreo-resinous. The white and milky pieces odorous, rather fragrant, somewhat resembling fine elemi; taste like the smell, and sweetish. One piece, indeed, had crevices, dividing it into laminæ, between which was compressed a subsaccharine pasty matter. Sp. gr. 1·04 to 1·06.

It is very inflammable, burns away with a clear bright flame, but does not drop.

By gentle heat it froths and swells, giving out water and aromatic oil, and becoming transparent; and on increasing the heat runs into a clammy fusion, but does not liquefy. Äfter cooling it is transparent, and nearly as hard and tough as shell lac. This change may be effected without heating it enough to impair its whiteness, even by powdering and heating gently over the sand-bath, when it agglutinates as it gives off its essential oil, but becomes hard again on cooling.

To try its solubility, 20 grains, dried as above, were treated with the following liquids, each six times the quantity of the resin.

$a$. Cold water for twenty-four hours dissolved very little, but acquired its odour, taste, and sweetness; lost its transparency, and rendered the resin also opake.

b. Boiling water four hours on the sand-bath dissolved about 1 grain and became milky, but retained little of the odour and taste, the essential oil having passed off in the steam.

c. Rectified spirit of wine, twenty-four hours, cold, dissolved nearly one half, leaving the residue soft and elastic, like birdlime.

d. Alcohol (tartarised), four hours, at about $90^{\circ}$, dissolved the whole, but on cooling deposited the elastic matter as left by $c$; this dried on the sand-bath, till crisp and beginning to discolour, weighed $8 \frac{1}{2}$ grains.

$e$. Pyroacetic spirit acted little upon it in the cold, leaving the residue partly pulverulent, partly glutinous and elastic.

$f$. Pyroacetic spirit tartarised (rectified over carbonate of potass) digested four hours in a warm-water bath, dissolved it very partially, acquiring no consistence, becoming milky, but not coagulating when dropped into water, and burning with the same bluish transparent smokeless flame as the pure spirit. No other instance occurs to my recollection in which the distinction between alcohol and pyroacetic spirit is so marked; the latter leaves the kauri resin even when combined with shell lac or common resin.

g. Volatile oil of turpentine, twenty-four hours in the cold, rendered the resin voluminous, soft, and opake, but dissolved very little. 
$h$. The same oil, in the water-bath four hours, dissolved nearly 9 grains; the residue not elastic, (as that of $c$ and $d$ from alcohol,) and when dry was partially soluble in cold anhydrous alcohol, the undissolved part then acquiring some elasticity.

$i$. The elastic deposit from alcohol $(c, d)$ was digested in oil of turpentine on the water-bath, by which almost the whole was dissolved; a small portion separating when cold in a soft bulky jelly.

$k$. To another alcoholic portion, as $d$, was added one third of its volume of turpentine solution, as $h$, with the residuum, both being warm; the solutions mixed freely and clear, and the heat being continued other four hours, the residue completely dissolved. The solution retained its transparency and deposited nothing on cooling. Thus the kauri resin is completely soluble in four times and a half its weight of alcohol with one and a half its weight of oil of turpentine, and acts as a medium to combine the menstrua.

l. Pyroacetic spirit was tried with oil of turpentine in the same manner, but refused either to combine with the turpentine, or to act effectively on the resin.

m. Coal-tar naphtha dissolved the greater part readily in the cold, leaving a soft gelatinous residue, like caoutchouc digested in that liquid.

$n$. Linseed oil did not dissolve it by digestion, nor by gently heating together in an iron ladle. On increasing the heat, combination takes place, but not till the hardness and elasticity of the resin are destroyed (v). The case is not amended by combining either the oil or the resin previously with oil of turpentine.

It was stated above that this resin wants fusibility; for although it easily softens and agglutinates, it refuses to liquefy, and even burns away without dropping.

To try how far this property could be induced:

$r$. A portion of the powder was mixed with half its weight of volatile oil of turpentine and gradually heated in an iron ladle. The resin softened as usual; the oil acquired consistence ; but the combination was only partial, though 'eept constantly stirring. The oil sradually evaporated, leaving the resin in its original clammy state, from which it did not change at any period of the experiment.

$s$. Another portion was mixed with half its weight of oil of turpentine, left in the cold for a night, and then digested six hours in a very gentle sand-bath. There were, as before, partial combinations between the mass of the resin and a part of the oil, and between the bulk of the oil and a part of the 
resin, but they always separated into a tough solid and a thickish liquid, however carefully mixed at every stage of the experiment; and the result in the iron ladle was as $(r)$.

t. Coal-tar naphtha entered fully into combination with kauri resin in the cold; but on applying heat no fluidity could be produced, the naphtha exhaled gradually, leaving the resin tough and clammy all through the experiment.

v. Mixed with one-eighth its weight of linseed oil, and gradually heated in the ladle, combination took place, with frothing just as the resin began to discolour. The whole became liquid, and poured easily out of the ladle. When cold it dropped readily on being kindled, and melted liquid at a moderate heat, but its valuable properties were destroyed. It had become more tender and crisp than common resin. And the same result followed when the combination was very slowly effected, and with a smaller proportion of oil.

w. Tallow, which forms a remarkably clammy compound with common resin, was substituted for linseed oil, with the kauri. But making the composition with whatever care, and in whatever proportions, the results were equally unfavourable.

$x$. Wax answered no better than tallow or linseed oil.

\section{Uses of Kauri Resin in the Arts.}

1. From its hardness, fragrancy, and brilliancy the white parts seem well suited for varnish making, for which its solubility in alcohol gives it great advantage. Harder and more free from colour than mastic, quite as soluble, and at perhaps less than one-tenth the price, it seems to be an important addition to our materials for alcoholic varnishes. It may indeed.come to be placed quite at their head. The alcoholic solution $d$, with one-fourth its measure of the turpentine solution $h$, is a very excellent spirit varnish, quite colourless, quick-drying, clear, and hard. The solution $k$ requires more care in application, being liable to precipitation as the alcohol dries away in the cold, but in a warm dry place it lies well, and gives a fine surface. Its insolubility in pyroacetic spirit is, however, an unfortunate limit to its utility as a material for varnish.

2. Its hardness, fragrancy, and inflammability pointed it out as suitable for sealing-wax, for which purpose the experiments on its fusibility were instituted. But they have not been successful in adapting it, per se, to that purpose. Combined, however, with lac and turpentine it answers much better, and the manufacturer will soon ascertain the best proportions. After many small experiments, the most successful with me has been: Kauri, lac, each one ounce; resin three 
quarters of an ounce, oil of turpentine half an ounce, vermilion one ounce. Powder together the lac, kauri, and resin; add the vermilion, and then the turpentine. Let them remain a few days in a well-covered vessel, then melt them together in a very gentle heat. The kauri will liquefy in this composition ; it burns well, drops freely, and takes a fine impression. But it does not always adhere firmly to the paper; a very serious defect, of which the cause or remedy has not hitherto occurred to me. The same thing sometimes happens with sealing-wax made of the usual ingredients, but less frequently than with kauri.

Another purpose for which its brilliant inflammability and comparative infusibility qualify it, if it come in largely and cheaply, is gas light. A modification of the oil gas apparatus would work it, and the material being supposed at one-fourth the price of oil, whilst the original outlay in laying pipes, \&c. would be in the same small proportion as for oil gas, it would stand a fair chance in competition with coal gas, and be much less disagreeable in dwelling-houses than any gas hitherto employed.

As to its officinal employment in medicine and surgery, time and experience only can indicate them. External application seems most suited for it; its masticatory employment is not very likely to be adopted in Europe.

The older transparent pieces do best for sealing-wax, for which their colour is not an objection. The recent white are most suitable for varnish, being first deprived of moisture by drying over a sand- or water-bath, when they become transparent, still remaining colourless.

XXXVIII. On the Variation of the Arbitrary Constants in Mechanical Problems. By J. W. Lubbock, Esq., F.R.S.

[Continued from vol, xi. p. 495.]

THE methods I employed with reference to the equations of motion expressed in terms of rectangular coordinates $x, y, z$, are very easily extended to the more general case when the equations of motion are in the well-known form

$$
\begin{array}{ll}
\frac{d s}{d t}+\frac{d U}{d \phi}+\frac{d R}{d \phi}=0 & T=\frac{x^{2}+y^{\prime 2}+z^{\prime 2}}{2} \\
\frac{d u}{d t}+\frac{d U}{d \psi}+\frac{d R}{d \psi}=0 & U=V-T \\
\frac{d v}{d t}+\frac{d U}{d \theta}+\frac{d R}{d \theta}=0 &
\end{array}
$$

